\title{
Shoot-foliage relationships in deciduous, semideciduous, and evergreen cerrado tree species
}

\author{
João Paulo Souza ${ }^{*}$, Carlos Henrique B. A. Prado ${ }^{2}$, Ana Lúcia S. Albino ${ }^{3}$ and Maria A. Damascos ${ }^{4}$ \\ ${ }^{1}$ Post-graduate program in Ecology and Natural Resources, Federal University of São Carlos, 13565-905, São \\ Carlos, São Paulo, Brazil. Current address: Department of Biological Sciences, Federal University of Goiás, \\ 75704-020, Catalão, Goiás, Brazil. \\ 2 Department of Botany, Federal University of São Carlos, 13565-905, São Carlos, São Paulo, Brazil. \\ ${ }^{3}$ Undergraduate of Biological Sciences, 13565-905, Federal University of São Carlos, São Carlos, São Paulo, Brazil. \\ ${ }^{4}$ National University of Comahue, Department of Botany, Quintral 1250, (8400) San Carlos de Bariloche, Argentina.
}

*Corresponding author: joaopaulobio@hotmail.com.

Received: 20 February 2009; Accepted: 15 June 2009

\begin{abstract}
The morphology and the biomass allocation in shoots and leaves were investigated in 15 cerrado tree species with distinct leaf phenology growing under natural conditions. Higher values of leaf/shoot ratio on mass base, individual leaf area, leaf area per shoot, leaf display index, and leaf number per shoot length were found in deciduous than in evergreen species. The differences about shootfoliage relationship across leaf phenological groups could be explained by plagiotropic shoots on deciduous and by erect shoots in semideciduous and evergreen species. Plagiotropic shoots allow similar irradiance along shoots and high biomass allocation in favor of leaves without foliage self-shading in deciduous tree species. The structural differentiation between short and long shoots was indicated by an exponential relationship between leaf display index and shoot length in all deciduous, in three semideciduous, and in two evergreen species. Therefore, especially in deciduous, the short shoots had higher leaf area per unit of length than the long shoots. The differentiation between short and long shoots depends on the shoot length in deciduous because of the leaf number on shoot is predetermined in buds. Contrastingly, the leaf neo-formation in semideciduous and in evergreen tree species keeps the shoot-leaf relationship per shoot length more constant, because of the foliage being produced according to the shoot growth during the year. In conclusion, the foliage persistence, the shoot inclination, the type of leaf production and the resources allocation between autotrophic and heterotrophic vegetative interdependent in cerrado tree species across different leaf phenological groups.
\end{abstract}

Key words: Biomass allocation, Cerrado, deciduousness, irradiance, leaf area, orthotropic, plagiotropic, shoot.

\section{RESUMO}

Variações na morfologia e alocação de biomassa em folhas e ramos foram investigadas em 15 espécies arbóreas de Cerrado com distintas fenologias foliares e crescendo em condições naturais. As espécies decíduas apresentaram maiores valores que as sempreverdes para razão entre massa de folhas e do ramo, área foliar individual, área foliar por ramo, índice de exposição foliar e número de folhas pelo comprimento do ramo. As diferenças acerca das relações ramo-folhagem entre os grupos fenológicos poderia ser explicada pelos ramos plagiotrópicos nas decíduas e pelos ramos eretos nas semidecíduas e sempre verdes. Ramos plagiotrópicos propiciam similar irradiância incidente ao longo do ramo e alta alocação de biomassa em favor das folhas sem auto-sombreamento da folhagem nas decíduas. A variação estrutural entre ramos curtos e longos foi indicada por uma relação exponencial entre 0 índice de exposição foliar com o comprimento do ramo em todas decíduas, em três semidecíduas e em duas 
sempreverdes. Assim, especialmente nas decíduas, ramos curtos apresentam maior área foliar por comprimento de ramo do que ramos longos. A diferenciação entre ramos curtos e longos depende do comprimento do ramo em todas as decíduas em função do número de folhas no ramo ser pré-determinado nas gemas. Diferentemente, a neo-formação de folhas nas semidecíduas e sempreverdes mantêm mais constante a relação ramo-folhagem por comprimento de ramo, pois a folhagem é produzida de acordo com o crescimento do ramo durante 0 ano. Em conclusão, persistência da folhagem, inclinação de ramo, tipo de produção foliar, e alocação de recursos entre componentes autotróficos e heterotróficos da copa são características interdependentes nas espécies arbóreas de Cerrado ao longo dos distintos grupos fenológicos foliares.

Palavras-chave: Alocação de biomassa, área foliar, Cerrado, deciduidade, irradiância, ortotrópico, plagiotrópico, ramo.

\section{INTRODUCTION}

Species with distinct patterns of leaf deciduousness cooccur in Cerrado vegetation with different kinds of ramification in canopy (Damascos et al., 2005) and different depths of the root system (Jackson et al., 1999). Evergreen trees of Cerrado show intense canopy branching with a higher number of shoots than the deciduous trees (Damascos et al., 2005). Besides, evergreen cerrado trees unfold the foliage through the apical meristem, which emits leaves continuously along the year (Damascos et al., 2005; Lenza and Klink, 2006). In contrast, deciduous tree species of Cerrado produce all leaves in a flush as a synchronic foliage production with leaf primordia pre-formed and enclosed in the buds (Damascos et al., 2005; Damascos, 2008). Notwithstanding, there were no differences concerning the leaf physiological traits as the stomatal conductance (Meinzer et al., 1999; Bucci et al., 2004; Prado et al., 2004; Franco et al., 2005) and photosynthetic capacity (Paula, 2002) among distinct leaf phenological groups of cerrado tree species during the growing season.

The relationship between autotrophic and heterotrophic parts in canopy should vary significantly across the leaf phenological groups, because cerrado trees have different kinds of shoot growth and foliage phenology. Variations about shoot morphology and biomass allocation should be linked with foliage self-shading along shoot inside the canopies of evergreen, semideciduous, and deciduous cerrado tree as found in tree species of temperate forest (Yagi and Kikuzawa, 1999; Yagi, 2000; Suzuki, 2003). The shoot inclination and the irradiance extinction along the shoot should have a strong impact on the structure and the biomass partitioning between autotrophic and heterotrophic parts of the canopy. Therefore, every leaf phenological group of cerrado trees probably has distinct shoot-foliage relationship as found in tree species of temperate forest (Takenaka, 1997).
Distinct patterns of biomass partitioning between shoots and leaves in same canopy could result in structural differentiation between short and long shoots (Takenaka, 1997; Yagi and Kikuzawa, 1999; Yagi, 2000). On the other hand, the kind of leaf production (synchronic or continuous) and different deciduousness in trees of Cerrado (Damascos et al., 2005; Lenza and Klink, 2006) could be related to structural differentiation in canopy. If deciduous species of Cerrado with synchronic leaf production have plagiotropic shoots, as in trees with synchronic leaf production in temperate forest, the irradiance will be equally distributed along shoots avoiding the foliage self-shading. This feature would allow high leaf area per shoot and high density of leaves in shoots of deciduous tree species. On the other hand, if continuous leaf production in semideciduous and evergreen cerrado trees takes place on orthotropic shoots, the extinction of irradiance will be strong from the apex to the base of the shoot as in trees with continuous leaf production in temperate forest. In this case, evergreen and semideciduous cerrado trees probably show low leaf area per shoot and low foliage density on shoot for avoiding the foliage self-shading in the same shoot.

The shoot-foliage relationships were investigated in some temperate tree species (Takenaka, 1997; Yagi and Kikuzawa, 1999; Yagi, 2000) but not yet in trees of Cerrado, a neotropical savanna differing from other savannas by its high diversity of woody species (Mendonça et al., 1998; Castro et al., 1999) and wide physiognomic range from grassland to tall woodlands (Sarmiento, 1984; Eiten, 1972). Therefore, the allocation pattern of biomass between shoot and foliage was investigated here in cerrado tree species with different leaf phenology growing under natural conditions in same area. Using this approach, it will be possible to verify if different leaf deciduousness in cerrado trees determines the shoot-foliage relationships across the leaf phenological groups. 


\section{MATERIALS AND METHODS}

Study area and climate: The study was carried out within a cerrado reservoir of 86 hectares, located in the northern of Federal University of São Carlos (UFSCar), in São Carlos municipality, Brazil $\left(22^{\circ} 00^{\prime}-22^{\circ} 30^{\prime} \mathrm{S}\right.$ and $47^{\circ} 30^{\prime}-$ $\left.48^{\circ} 00^{\prime} \mathrm{W}\right)$. The topography of the study area presents slight undulation at $850 \mathrm{~m}$ above sea level. The trees analysed in this study were distributed in 1 ha inside the physiognomy of the stricto sensu cerrado vegetation, where the water table was 10 meters deep (Kanno, 1998) and the soil was classified as dystrophic oxisol and poor in nutrients (Paula, 2002). This cerrado physiognomy is characterized by woody stratum formed by trees and shrubs on a well defined graminaceous layer (Ribeiro and Walter, 1998).

According to Köppen's climatic classification the regional climate in the study area is tropical with dry winter and wet summer (Aw). There are two well-defined seasons: the rainy season between October-March and the dry season between April-September (Prado et al., 2004; Monteiro and Prado, 2006). The mean value of total annual precipitation is $1420 \mathrm{~mm}$ and the average of annual air temperature is $22^{\circ} \mathrm{C}$ in period from 19392007. Shoots and leaves were collected at the end of the rainy season (April 2007) on Casearia sylvestris, Diospyros hispida, Eriotheca gracilipes, Kielmeyera variabilis, Miconia ligustroides and Piptocarpha rotundifolia, and in April 2008 on the other tree species (Table 1).
Plant species: The species of trees studied (Table 1) were separated according to distinct leaf phenological groups (deciduous, semideciduous, and evergreen) and are well represented in the study area (Oliveira and Batalha, 2005). Five adult individuals per species were selected growing under full solar irradiance. The deciduous species (DE) shed leaves at the end of dry season remaining leafless for about 30 days (Paula, 2002; Damascos et al., 2005; Damascos, 2008). Semideciduous species (SD) shed around a half of their leaves at the end of dry season. In contrast, the evergreen species (EV) of studied trees keep almost the same foliar area during the whole year (Paula, 2002; Lenza and Klink, 2006; Damascos, 2008).

Shoot and leaf dry mass, shoot length and leaf area measurements: Five adult individuals with similar height and stem circumference at breast height were utilized in each species (Table 1) for quantifying the shoot length, the shoot dry mass, and the leaf area, leaf mass, and the number of leaves per shoot. Ten lateral buds on 10 shoots (one bud per shoot) were marked in each individual tree in July 2006 or in July 2007 (Table 1) at the peak of dry season. The development of the marked buds was monitored once every five days as of the bud break and the corresponding leaf unfold and shoot elongation. After the whole growth season (from July 2006 to April 2007 or from July 2007 to April 2008) the 10 shoots previously monitored were detached in each individual resulting in 50 shoots collected per species.

Table 1. Mean values $( \pm S E, n=5)$ of height, circumference at breast height $(C B H)$, and foliage traits of 15 cerrado tree species. Sy=synchronic, $C 0=$ continuous, $\mathrm{Sp}=\mathrm{Spiral}, \mathrm{Al}=$ alternate, $\mathrm{Op}=$ opposite and decusate, $\mathrm{Si}=$ simple, $\mathrm{Cm}=$ compound, $\mathrm{DE}=$ deciduous, $\mathrm{SD}=$ semideciduous, $\mathrm{EV}=$ evergreen.

\begin{tabular}{|c|c|c|c|c|c|}
\hline Species & Height (cm) & CBH (cm) & Phyllotaxy/ Leaf type & Pattern of leaf Production ${ }^{\mathrm{a}}$ & Leaf phenology ${ }^{\mathrm{a}}$ \\
\hline Anadenanthera falcata (Benth.) Speg. (Mimosaceae) ${ }^{\star \star}$ & $194 \pm 9$ & $11.8 \pm 2.1$ & $\mathrm{Al} / \mathrm{Cm}$ & Sy & $\mathrm{DE}$ \\
\hline Aspidosperma tomentosum Mart. (Apocynaceae) ${ }^{\star *}$ & $300 \pm 32$ & $13.6 \pm 1.2$ & $\mathrm{Sp} / \mathrm{Si}$ & Sy & $\mathrm{DE}$ \\
\hline Caryocar brasiliense Cambess. (Caryocaraceae) ${ }^{\star \star}$ & $172 \pm 8$ & $14.4 \pm 1.4$ & Op/Cm & Sy & $\mathrm{DE}$ \\
\hline Diospyros hispida A. DC. (Ebenaceae)* & $250 \pm 18$ & $16.6 \pm 1.4$ & $\mathrm{Sp} / \mathrm{Si}$ & Sy & $\mathrm{DE}$ \\
\hline Kielmeyera variabilis Mart. \& Zucc. (Clusiaceae)* & $226 \pm 22$ & $20.4 \pm 3.4$ & $\mathrm{Sp} / \mathrm{Si}$ & Sy & $\mathrm{DE}$ \\
\hline Casearia sylvestris Sw. (Salicaceae)* & $164 \pm 11$ & $8.6 \pm 0.4$ & $\mathrm{Al} / \mathrm{Si}$ & Co & SD \\
\hline Eriotheca gracilipes (K. Schum) A. Robyns (Malvaceae)* & $178 \pm 23$ & $13.6 \pm 2.7$ & $\mathrm{Al} / \mathrm{Cm}$ & Co & SD \\
\hline Stryphnodendron adstringens (Mart.) Coville (Mimosaceae) ${ }^{\star \star}$ & $288 \pm 38$ & $15.2 \pm 0.7$ & $\mathrm{Sp} / \mathrm{Cm}$ & Co & SD \\
\hline Stryphnodendron polyphyllum Mart. (Mimosaceae) ${ }^{\star *}$ & $202 \pm 4$ & $13.8 \pm 1.3$ & $\mathrm{Sp} / \mathrm{Cm}$ & Co & SD \\
\hline Tibouchina stenocarpa (DC.) Cogn. (Melastomataceae) ${ }^{\star \star}$ & $186 \pm 7$ & $9.8 \pm 1.2$ & Op/Si & Co & SD \\
\hline Connarus suberosus Planch. (Connaraceae) ${ }^{\star \star}$ & $252 \pm 31$ & $22.0 \pm 2.1$ & $\mathrm{Sp} / \mathrm{Cm}$ & Co & EV \\
\hline Miconia albicans (Sw.) Triana (Melastomataceae) ${ }^{\star *}$ & $192 \pm 10$ & $7.0 \pm 0.5$ & Op/Si & Co & EV \\
\hline Miconia ligustroides (DC.) Naudin (Melastomataceae)* & $244 \pm 46$ & $13.8 \pm 3.3$ & Op/Si & Co & EV \\
\hline Piptocarpha rotundifolia (Less.) Baker (Asteraceae)* & $238 \pm 43$ & $18.2 \pm 3.6$ & $\mathrm{Al} / \mathrm{Si}$ & Co & EV \\
\hline Styrax camporum Pohl (Styracaceae) ${ }^{\star \star}$ & $308 \pm 47$ & $21.2 \pm 3.3$ & $\mathrm{Sp} / \mathrm{Si}$ & Co & EV \\
\hline
\end{tabular}

Data obtained on shoots in $2007\left({ }^{*}\right)$ and $2008\left({ }^{* *}\right)$. According to Paula (2002) and our previous observations. 
The number of leaves per shoot (LN) was determined on each one of 10 detached shoots in every individual tree in each species ( $n=50$ shoots per species). The length (SL) and the dry mass (SM) of every shoot was determined separately. The dry mass of each shoot was acquired after removing all lateral buds and leaves, when the area and the mass of leaves were also determined. The leaf area was obtained on each individual leaf using the software Pro-Image version 4.0 (Media Cybernetics, USA). Shoots and leaves were dried in a stove under $60^{\circ} \mathrm{C}$ up to constant weight (Cornelissen et al., 2003), which was measured in an analytical balance (Mettler AE260 DeltaRange). All leaves on shoots were considered independent of their size and age. The leaf area per shoot (LA) was obtained through the summation of all leaf area on a corresponding shoot. Using this method, it was possible to acquire the dry mass and the length of shoots, the leaf number, the mass of leaves, and the leaf area per shoot in every one of 50 shoots collected per tree species.

\section{Shoot inclination and the irradiance along shoot:}

The shoot inclination and the irradiance along shoot were determined in April 2006 on Casearia sylvestris, Diospyros hispida, Eriotheca gracilipes, Kielmeyera variabilis, Miconia ligustroides and Piptocarpha rotundifolia, and in April 2008 on the other tree species (Table 1). Five adult individuals of each species growing under full irradiance and with similar height of those used in shoot-leaf relationship determinations were marked for acquiring the angle of insertion of current-year shoots produced on previous growing season. These shoots were identified by supporting new green leaves, located at the periphery of the canopy and on thicker parental shoots usually free of leaves. A thin horizontal bar crossed by $2.0 \mathrm{~m}$ vertical bar was located at the insertion of each current-year shoot. A plummet was utilized for checking the perpendicular position of vertical bar in each angle measured. The thin horizontal bar was used as reference to determine the angle between the current-year shoot and the horizon by means of a compass. Ten current-year shoots in each individual were used for determining the mean value of the angle of the shoot insertion ( $n=50$ shoots per species).

The irradiance along current-year shoots was determined at $1200 \mathrm{~h}$ with a Phywe luxmeter (Göttingen, Germany). Full solar irradiance (considered as 100\%) was measured in open area of cerrado stricto sensu holding the luxmeter probe parallel to the solar beans. The luxmeter sensor on the top of the probe was placed on the same position of the leaf blade in relation to the solar beans along the current-year shoots. Therefore, the irradiance was not $100 \%$ even on distal leaves on the shoot apex, because of the leaf blade was not exactly at the right angle in relation to the solar beans. The irradiance on the apex, middle and at the base of the shoots was determined in five current-year shoots in each one of the five individuals previously marked for measuring the shoot inclination $(n=25$ shoots per species).

Shoot-foliage relationships: The Shoot-foliage relationships were accomplished according to Yagi and Kikuzawa (1999) and Yagi (2000). These relationships reveal the pattern of the foliage distribution, the biomass allocation among shoots and the strategies of resources optimization in canopy. Besides, through these shoot-foliage relationships it is possible to identify the variations between species or groups of species. Parameters determined were the leaf display index ( $\mathrm{LDI}=$ shoot leaf area by shoot length, $\mathrm{cm}^{2} \mathrm{~cm}^{-1}$ ); the density of leaf number (DLN=leaf number by shoot length, leaf $\mathrm{cm}^{-1}$ ); the individual leaf area (ILA=leaf area by leaf number per shoot, $\mathrm{cm}^{2}$ ); and the leaf/shoot ratio (LSR =total leaf dry mass by total shoot dry mass, $\mathrm{g} \mathrm{g}^{-1}$ ). The structural traits about linear measurements (SL and DLN), leaf area (ILA, LA, LDI) and biomass (LSR and $S M)$ were related with shoot length for depicting the patterns of shoot-foliage relationships in each species separately and in every leaf phenological group according to Yagi and Kikuzawa (1999) and Yagi (2000).

Data analyzes: The average values \pm standard errors (SE) of shoot length (SL), leaf area per shoot (LA), leaf number per shoot $(\mathrm{LN})$, leaf display index (LDI), density of leaf number (DLN), individual leaf area (ILA), leaf/ shoot ratio (LSR), shoot inclination, and the percentage of irradiance along shoot were calculated separately in each species and in every leaf phenological group. The KruskalWallis and the pos-hoc Dunn test (Zar, 1999) were used to investigate possible differences in traits cited above (except to the percentage of irradiance) among species or among leaf phenological groups. The percentage of irradiance was compared along shoot (apex, middle and base) in each species separately and in every leaf phenological group using the Kruskal-Wallis test (Zar, 1999).

We used the best adjustment of curves to analyze the relationships between $L A, S M, L D I, D L N$, and LSR as a 
function of SL, which indicated the best regression to fit each data set with SL. The regressions were fitted by means of the software Origin, version 7.0 (OriginLab Corporation). The relationships between DLN, LDI, and LSR with SL were fitted by an exponential decay and the relationships between LA and SM with SL by the linear regression. The principal component analyzes (PCA) was accomplished considering all variables (shoot inclination, LA, DLN, LDI, ILA, LN, SL, and LSR) for verifying the clustering behavior of tree species in a 2-dimensional space. The PCA was carried out using MVSP program, version 3.1 (Kovach Computing Services).

\section{RESULTS}

Higher values of leaf area per shoot $(L A)$, leaf display index (LDI), density of leaf number (DLN), individual leaf area (ILA), and leaf/shoot ratio (LSR) were found in deciduous rather than in semideciduous and evergreen species (Table 2). For instance, the average values of $L A, L D I, D L N, I L A$, and LSR were 2, 10, 3,3 and 2 times higher in deciduous than in evergreen species, respectively. On the other hand, in semideciduous species, intermediate values could be found concern the variables of shoot-foliage relationships (Table 2). Only the leaf number per shoot (LN) and the shoot length (SL) were higher in evergreen than in deciduous species (Table 2).

Table 2. Mean values \pm SE of leaf area per shoot $\left(\mathrm{LA}, \mathrm{cm}^{2}\right)$, leaf number per shoot $(\mathrm{LN})$, shoot length (SL), and variables of shoot-foliage relationships in $15 \mathrm{cerrado}$ tree species. $\mathrm{LDI}=$ leaf display index $\left(\mathrm{cm}^{2} \mathrm{~cm}^{-1}\right), \mathrm{DLN}=$ density of leaf number $\left(\right.$ leaf $\left.\mathrm{cm}^{-1}\right), \mathrm{ILA}=$ individual leaf area $\left(\mathrm{cm}^{2}\right), \mathrm{LSR}=1$ eaf $\left./ \mathrm{shoot} \mathrm{ratio}(\mathrm{g} \mathrm{g})^{-1}\right)$. Different letters after mean values in columns indicate significant differences $(p<0.05$, Kruskal-Wallis) among species or among leaf phenological groups. $n=50$ shoots for each species. Mean values \pm SE in each phenological group are in bold.

\begin{tabular}{|c|c|c|c|c|c|c|c|c|}
\hline $\begin{array}{l}\text { Leaf phenological } \\
\text { group }\end{array}$ & Species & LA & LN & SL & LDI & DLN & ILA & LSR \\
\hline \multirow[t]{6}{*}{ Deciduous } & A. falcata & $334 \pm 23$ bc & $4.0 \pm 0.2 \mathrm{~h}$ & $5.4 \pm 1$ de & $70.0 \pm 5.4 \mathrm{~b}$ & $0.85 \pm 0.05 b c$ & $82.0 \pm 4.2 \mathrm{ab}$ & $22.2 \pm 1.6 \mathrm{a}$ \\
\hline & A. tomentosum & $399 \pm 40$ bc & $6.3 \pm 0.5 \mathrm{efg}$ & $1.9 \pm 1 f$ & $274.0 \pm 22.4 \mathrm{a}$ & $4.46 \pm 0.31 \mathrm{a}$ & $61.8 \pm 2.8 \mathrm{~b}$ & $11.1 \pm 0.8 b c$ \\
\hline & C. brasiliense & $503 \pm 36 a b$ & $3.3 \pm 0.2 \mathrm{~h}$ & $8.9 \pm 1 \mathrm{~cd}$ & $87.1 \pm 9.4 b$ & $0.61 \pm 0.06$ de & $153.4 \pm 7.6 \mathrm{a}$ & $8.6 \pm 0.9$ def \\
\hline & D. hispida & $577 \pm 41 \mathrm{a}$ & $9.7 \pm 0.4 b c$ & $9.5 \pm 1 \mathrm{bcd}$ & $64.1 \pm 2.9 \mathrm{~b}$ & $1.12 \pm 0.06 b$ & $61.9 \pm 3.2 \mathrm{~b}$ & $8.0 \pm 0.5 \mathrm{bcd}$ \\
\hline & K. variabilis & $283 \pm 18 \mathrm{~cd}$ & $10.8 \pm 0.7 a b$ & $16.2 \pm 1 \mathrm{ab}$ & $35.9 \pm 6.3 c$ & $1.11 \pm 0.12 b c$ & $27.7 \pm 1.7 \mathrm{~cd}$ & $5.0 \pm 0.8 \mathrm{~g}$ \\
\hline & Mean ( $\pm S E)$ & $419 \pm 16 a$ & $6.8 \pm 0.3 b$ & $8.4 \pm 1 \mathrm{C}$ & $106.4 \pm 7.5 \mathrm{a}$ & $1.64 \pm 0.12 a$ & $77.5 \pm 3.3 \mathrm{a}$ & $11.0 \pm 0.6 \mathrm{a}$ \\
\hline \multirow[t]{6}{*}{ Semideciduous } & C. sylvestris & $90 \pm 6 f$ & $13.5 \pm 0.4 \mathrm{a}$ & $17.6 \pm 1 \mathrm{a}$ & $5.0 \pm 0.2 f$ & $0.79 \pm 0.02 b c$ & $6.5 \pm 0.3 \mathrm{~g}$ & $5.9 \pm 0.2$ defg \\
\hline & E. gracilipes & $245 \pm 20$ cde & $3.4 \pm 0.2 \mathrm{~h}$ & $11.9 \pm 1 b c$ & $266 \pm 2.1 \mathrm{c}$ & $0.47 \pm 0.05 \mathrm{e}$ & $72.3 \pm 5.5 b$ & $8.1 \pm 0.7$ cdef \\
\hline & S. adstringens & $857 \pm 88 a$ & $4.4 \pm 0.3 \mathrm{gh}$ & $3.8 \pm 1$ ef & $225.5 \pm 15.3 \mathrm{a}$ & $1.34 \pm 0.10 b$ & $199.6 \pm 15.1 a$ & $9.4 \pm 0.7 \mathrm{bcd}$ \\
\hline & S. polyphyllum & $564 \pm 35 a$ & $7.6 \pm 0.5 \mathrm{cde}$ & $8.0 \pm 1$ cde & $76.5 \pm 3.7 \mathrm{ab}$ & $1.01 \pm 0.05 b$ & $79.4 \pm 3.9 \mathrm{ab}$ & $11.0 \pm 0.7 \mathrm{ab}$ \\
\hline & T. stenocarpa & $102 \pm 7 f$ & $6.8 \pm 0.2 \mathrm{def}$ & $14.1 \pm 1 a b$ & $7.5 \pm 0.5 \mathrm{def}$ & $0.53 \pm 0.03 \mathrm{de}$ & $14.6 \pm 0.7 \mathrm{efg}$ & $4.3 \pm 0.3 \mathrm{~g}$ \\
\hline & Mean ( \pm SE) & $372 \pm 27$ b & $7.2 \pm 0.3 b$ & $11.1 \pm 1 b$ & $68.5 \pm 6.2 \mathrm{~b}$ & $0.83 \pm 0.03 b$ & $74.2 \pm 5.5 \mathrm{~b}$ & $7.7 \pm 0.3 b$ \\
\hline \multirow[t]{6}{*}{ Evergreen } & C. suberosus & $160 \pm 11$ ef & $7.7 \pm 0.3$ bcde & $18.5 \pm 1 \mathrm{a}$ & $8.8 \pm 0.5 \mathrm{def}$ & $0.44 \pm 0.02 \mathrm{e}$ & $20.7 \pm 1.2 \mathrm{cdef}$ & $6.9 \pm 0.3$ bcde \\
\hline & M. albicans & $146 \pm 9$ ef & $5.3 \pm 0.3 \mathrm{fg}$ & $14.9 \pm 1 \mathrm{ab}$ & $10.3 \pm 0.5 \mathrm{de}$ & $0.40 \pm 0.02 \mathrm{e}$ & $27.4 \pm 1.1 \mathrm{c}$ & $5.1 \pm 0.3 \mathrm{fg}$ \\
\hline & M. ligustroides & $101 \pm 8 f$ & $8.6 \pm 0.5 \mathrm{bcd}$ & $14.5 \pm 1 \mathrm{ab}$ & $7.0 \pm 0.3 \mathrm{def}$ & $0.65 \pm 0.03 \mathrm{~cd}$ & $11.3 \pm 0.5 f g$ & $4.6 \pm 0.4 \mathrm{~g}$ \\
\hline & P. rotundifolia & $214 \pm 19$ de & $7.9 \pm 0.4$ bcde & $18.2 \pm 2 a b$ & $12.4 \pm 0.6 \mathrm{~cd}$ & $0.57 \pm 0.04 \mathrm{de}$ & $25.6 \pm 1.8 \mathrm{cde}$ & $5.8 \pm 0.4 \mathrm{efg}$ \\
\hline & S. camporum & $139 \pm$ ef & $9.5 \pm 0.6 \mathrm{bcd}$ & $15.3 \pm 1 a b$ & $9.9 \pm 0.7$ ef & $0.68 \pm 0.04 \mathrm{~cd}$ & $15.1 \pm 0.8 \mathrm{def}$ & $6.2 \pm 0.4$ defg \\
\hline & Mean ( \pm SE) & $152 \pm 6 \mathrm{c}$ & $7.8 \pm 0.2 \mathrm{a}$ & $16.3 \pm 1 \mathrm{a}$ & $9.7 \pm 0.3 \mathrm{c}$ & $0.55 \pm 0.02 c$ & $20.1 \pm 0.6 \mathrm{c}$ & $5.7 \pm 0.2 \mathrm{c}$ \\
\hline
\end{tabular}


On average, deciduous trees had values of shoot inclination equal to $42^{\circ}$ in relation to horizon, but semideciduous and evergreen species showed shoots in more erect positions, with $54^{\circ}$ and $62^{\circ}$, respectively (Table 3). The irradiance was similar $(p>0.05)$ along the shoots in deciduous (Table 3 ) in which $80 \%$ of total irradiance was obtained on the base of the shoots. In contrast, the irradiance on the base of erected shoots in semideciduous and evergreen trees was only 26 and $12 \%$, respectively. Hence, there was strong irradiance attenuation from the apex to the base of the erected shoots, especially in evergreen species (Table 3).

Table 3. Mean values $\pm S E$ of shoot inclination in relation to the horizon and the percentage of solar irradiance along shoots in relation to an open area considered as $100 \%$ of irradiance in cerrado stricto sensu physiognomy. Different letters after mean values in columns indicate significant differences $(p<0.05)$ among species or leaf phenological groups. Different letters after mean values in lines of irradiance indicate significant differences $(p<0.05)$ in same species or in same leaf phenological group. Mean values \pm SE in each phenological group are in bold.

\begin{tabular}{|c|c|c|c|c|c|}
\hline \multirow[t]{2}{*}{ Leaf phenological group } & \multirow[t]{2}{*}{ Cerrado tree species } & \multirow[t]{2}{*}{ Angle of shoot inclination ${ }^{\mathrm{a}}$} & \multicolumn{3}{|c|}{ Irradiance along shoots (\% in relation to open area) } \\
\hline & & & Apex & Middle & Base \\
\hline \multirow[t]{6}{*}{ Deciduous } & A. falcata & $41 \pm 2 \mathrm{e}$ & $84 \pm 2 a$ & $87 \pm 2 a$ & $84 \pm 3 a$ \\
\hline & A. tomentosum & $40 \pm 1 \mathrm{e}$ & $72 \pm 4 a$ & $74 \pm 4 a$ & $69 \pm 3 a$ \\
\hline & C. brasiliense & $40 \pm 2 \mathrm{e}$ & $83 \pm 4 a$ & $79 \pm 5 \mathrm{a}$ & $78 \pm 4 \mathrm{a}$ \\
\hline & D. hispida & $46 \pm 3$ de & $84 \pm 2 a$ & $83 \pm 1 \mathrm{a}$ & $83 \pm 2 \mathrm{a}$ \\
\hline & K. variabilis & $43 \pm 3$ de & $87 \pm 2 \mathrm{a}$ & $84 \pm 3 a$ & $87 \pm 2 \mathrm{a}$ \\
\hline & Mean $( \pm S E)$ & $42 \pm 1 c$ & $82 \pm 2$ a & $81 \pm 2 a$ & $80 \pm 3 a$ \\
\hline \multirow[t]{6}{*}{ Semideciduous } & C. sylvestris & $59 \pm 3 a b$ & $77 \pm 4 \mathrm{a}$ & $53 \pm 6 b$ & $14 \pm 3 c$ \\
\hline & E. gracilipes & $53 \pm 3$ bcd & $76 \pm 4 \mathrm{a}$ & $48 \pm 6 b$ & $31 \pm 6 b$ \\
\hline & S. adstringens & $51 \pm 2$ cde & $74 \pm 3 a$ & $47 \pm 5 b$ & $28 \pm 4 c$ \\
\hline & S. polyphyllum & $46 \pm 2$ de & $90 \pm 1 \mathrm{a}$ & $67 \pm 6 b$ & $41 \pm 5 c$ \\
\hline & T. stenocarpa & $60 \pm 2 a b c$ & $87 \pm 2 \mathrm{a}$ & $51 \pm 7 b$ & $14 \pm 3 c$ \\
\hline & Mean $( \pm$ SE) & $54 \pm 1 b$ & $81 \pm 3 a$ & $53 \pm 4 b$ & $26 \pm 5 c$ \\
\hline \multirow[t]{6}{*}{ Evergreen } & C. suberosus & $61 \pm 2 a b c$ & $71 \pm 4 \mathrm{a}$ & $51 \pm 6 b$ & $14 \pm 3 c$ \\
\hline & M. albicans & $63 \pm 2 a b$ & $83 \pm 3 a$ & $46 \pm 5 b$ & $10 \pm 3 b$ \\
\hline & M. ligustroides & $66 \pm 2 \mathrm{a}$ & $76 \pm 2 a$ & $45 \pm 6 b$ & $10 \pm 3 c$ \\
\hline & P. rotundifolia & $59 \pm 2 a b c$ & $74 \pm 5 a$ & $59 \pm 6 b$ & $5 \pm 1 c$ \\
\hline & S. camporum & $61 \pm 2 a b c$ & $56 \pm 4 \mathrm{a}$ & $31 \pm 5 \mathrm{a}$ & $19 \pm 4 b$ \\
\hline & Mean $( \pm$ SE) & $62 \pm 1 \mathrm{a}$ & $72 \pm 4 \mathrm{a}$ & $46 \pm 5 \mathrm{~b}$ & $12 \pm 2 \mathrm{c}$ \\
\hline
\end{tabular}

${ }^{\text {a} K r u s k a l l-W a l i s ~}$

LA and shoot dry mass (SM) increased with shoot length (SL) in all species (Figures 1 and 2), but the increment was proportionately higher in deciduous (Aspidosperma tomentosum, Diospyros hispida and Anadenanthera falcata) and in semideciduous (Stryphnodendron adstringens and Stryphnodendron polyphyllum) species. The density of leaf number (DLN) and the leaf/shoot ratio (LSR) showed an exponential decay with $\mathrm{SL}$ in all species (Figures 3 and 4 , $p<0.05)$ but this behavior was more evident in deciduous trees in which most shoots less than $10 \mathrm{~cm}$ had high DLN (Table 2). Therefore, unlike semideciduous and evergreen, the DLN decreasing with shoot length was steeper in deciduous species (Figure 3). 


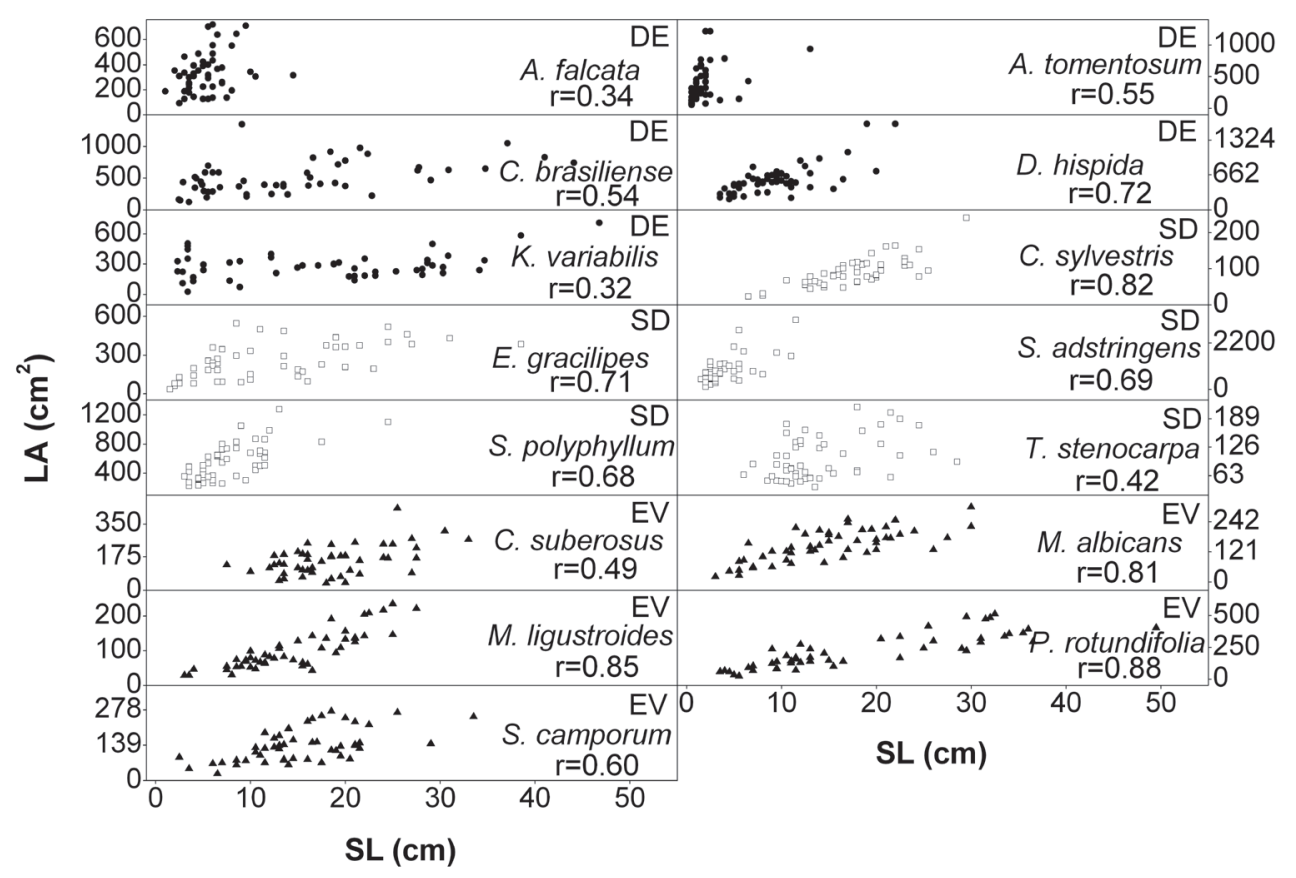

Figure 1. Total leaf area $\left(\mathrm{LA}, \mathrm{cm}^{2}\right)$ per shoot as a function of shoot length $(\mathrm{SL}, \mathrm{cm})$ in 15 cerrado tree species: deciduous $(\mathrm{DE}, \bullet)$, semideciduous $(\mathrm{SD}, \square)$ and evergreen $(E V, \mathbf{\Lambda})$. The coefficient of regression $(r)$ is shown in each panel $(p<0.05), n=50$ shoots per species.

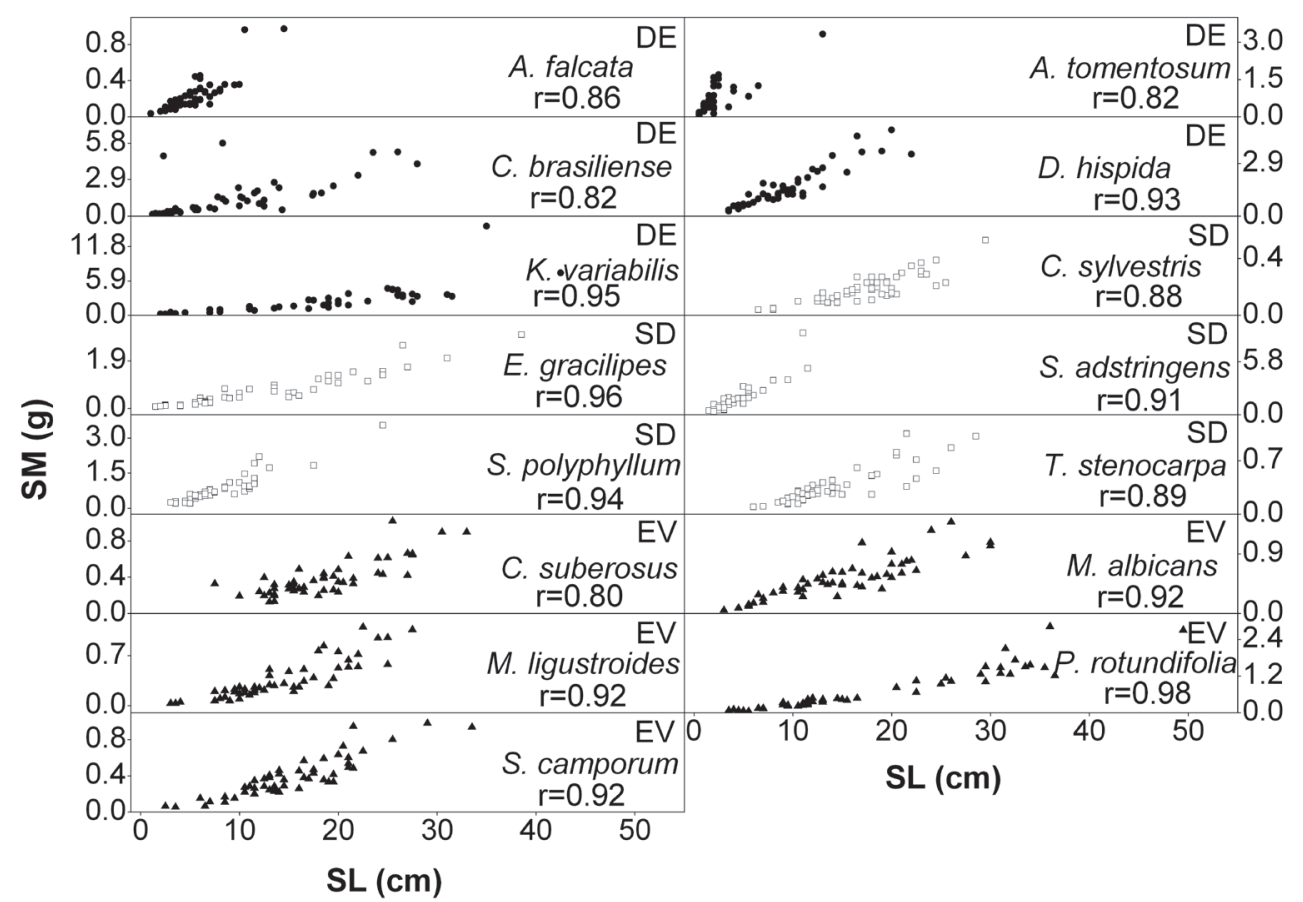

Figure 2. Shoot mass $(\mathrm{SM}, \mathrm{g})$ as a function of shoot length $(\mathrm{SL}, \mathrm{cm})$ in 15 cerrado tree species: deciduous $(\mathrm{DE}, \bullet)$, semideciduous $(\mathrm{SD}, \square)$ and evergreen $(\mathrm{EV}, \mathbf{\Lambda})$. The coefficient of regression $(r)$ is shown in each panel $(p<0.05), n=50$ shoots per species. 


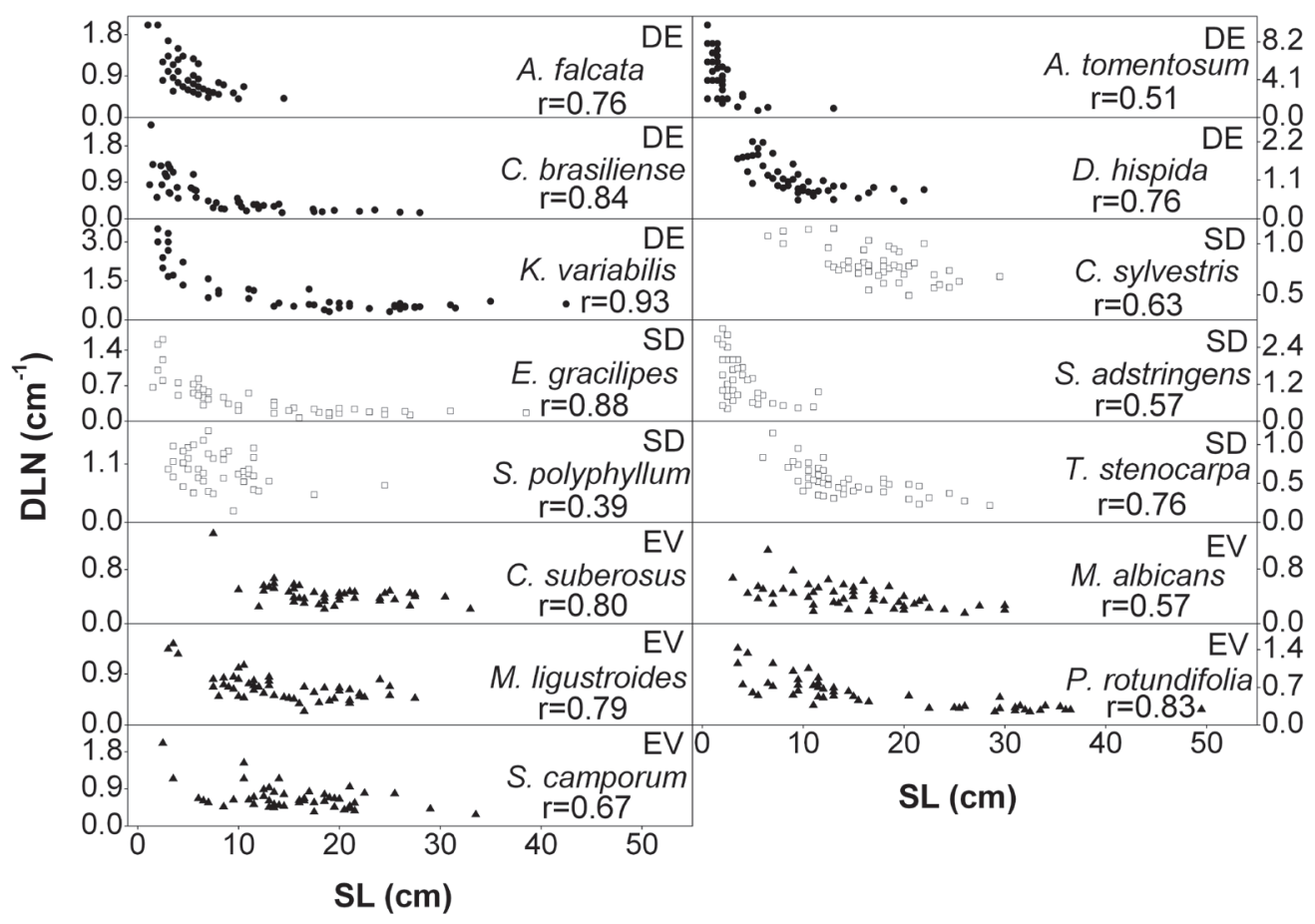

Figure 3. Density of leaf number (DLN, $\left.\mathrm{cm}^{-1}\right)$ as a function of shoot length $(\mathrm{SL}, \mathrm{cm})$ in 15 cerrado tree species: deciduous $(\mathrm{DE}, \bullet)$, semideciduous $(\mathrm{SD}, \square)$ and evergreen ( $E V, \boldsymbol{\Delta})$. The coefficient of regression $(r)$ is shown in each panel $(p<0.05), n=50$ shoots per species.

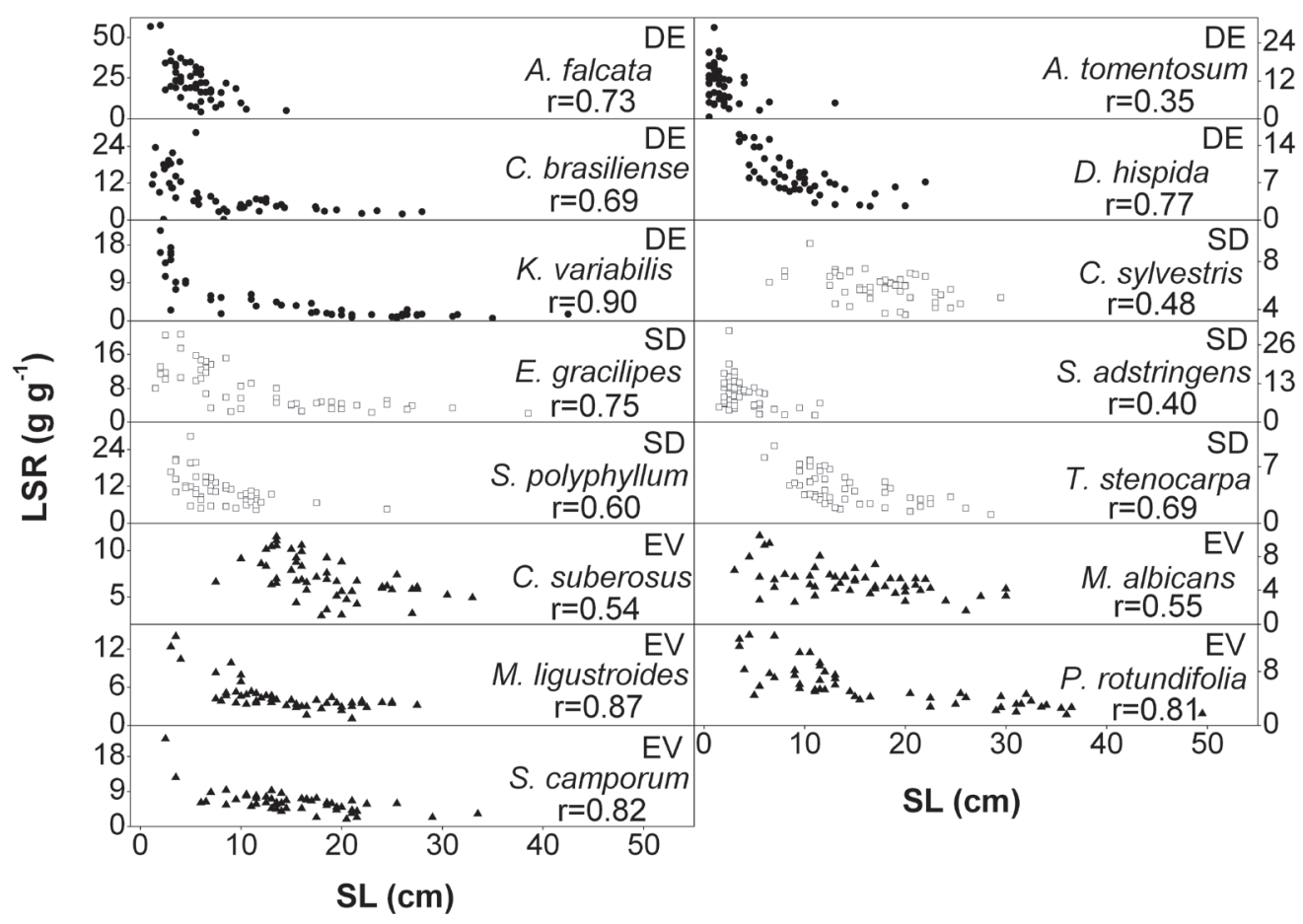

Figure 4. Leaf/shoot ratio $\left(\mathrm{LSR}, \mathrm{g} \mathrm{g}^{-1}\right)$ as a function of shoot length $(\mathrm{SL}, \mathrm{Cm})$ in 15 cerrado tree species: deciduous $(\mathrm{DE}, \bullet)$, semideciduous $(\mathrm{SD}$, ) and evergreen $(\mathrm{EV}, \mathbf{\Delta})$. The coefficient of regression $(r)$ is shown in each panel $(p<0.05), n=50$ shoots per species. 
The semideciduous species Stryphnodendronadstringes and Casearia sylvestris and the evergreen species Piptocarpha rotundifolia, Miconia ligustroides and Miconia albicans did not show significant relationship $(p>0.05)$ between LDI and SL
(Figure 5). On the other hand, LDI decreased exponentially as a function of $\mathrm{SL}$ in other 10 studied species. The drop of LDI was steeper in deciduous than in semideciduous and evergreen species considering the $\mathrm{SL}$ from 2 to $10 \mathrm{~cm}$.

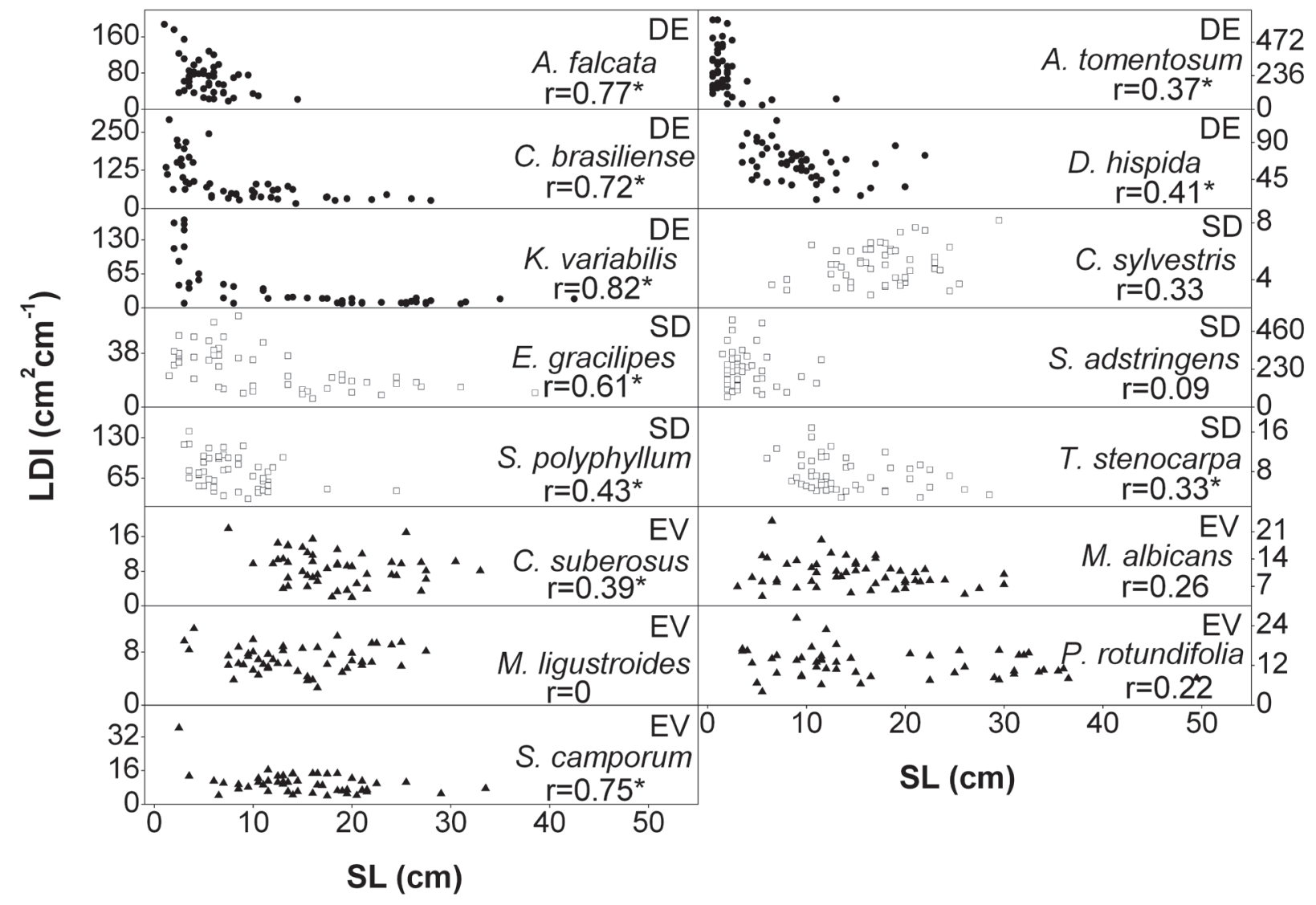

Figure 5. Leaf display index $\left(\mathrm{LDI}, \mathrm{cm}^{2} \mathrm{~cm}^{-1}\right)$ as a function of shoot length $(\mathrm{SL}, \mathrm{cm})$ in 15 cerrado tree species: deciduous $(\mathrm{DE}, \bullet)$, semideciduous $(\mathrm{SD}$, $\square)$ and evergreen $(E V, \boldsymbol{\Delta})$. The coefficient of regression $(r)$ is shown in each panel $\left({ }^{*} p<0.05\right), n=50$ shoots per species.

The axes 1 and 2 in PCA output accounted for 59 and $16 \%$ of total variation of data set, respectively (Figure 6 ). The symbols representing the tree species are distributed principally along the axis 1 . The evergreen species appeared at the left side of PCA as a group of symbols near each other, what means low variation in the pool of variables considered. Contrastingly, deciduous species appeared, with exception of Kielmeyera variabilis, at the right side of the PCA output in a higher dispersion than evergreen species (Figure 6). Semideciduous species did not show the clustering behavior along the two axis of the PCA. Indeed, semideciduous species showed the highest dispersion among the leaf phenological groups studied, indicating the greatest variation in the pool of variables about shoot, leaf and shoot-leaf relationship utilized in PCA analyses (Figure 6). 


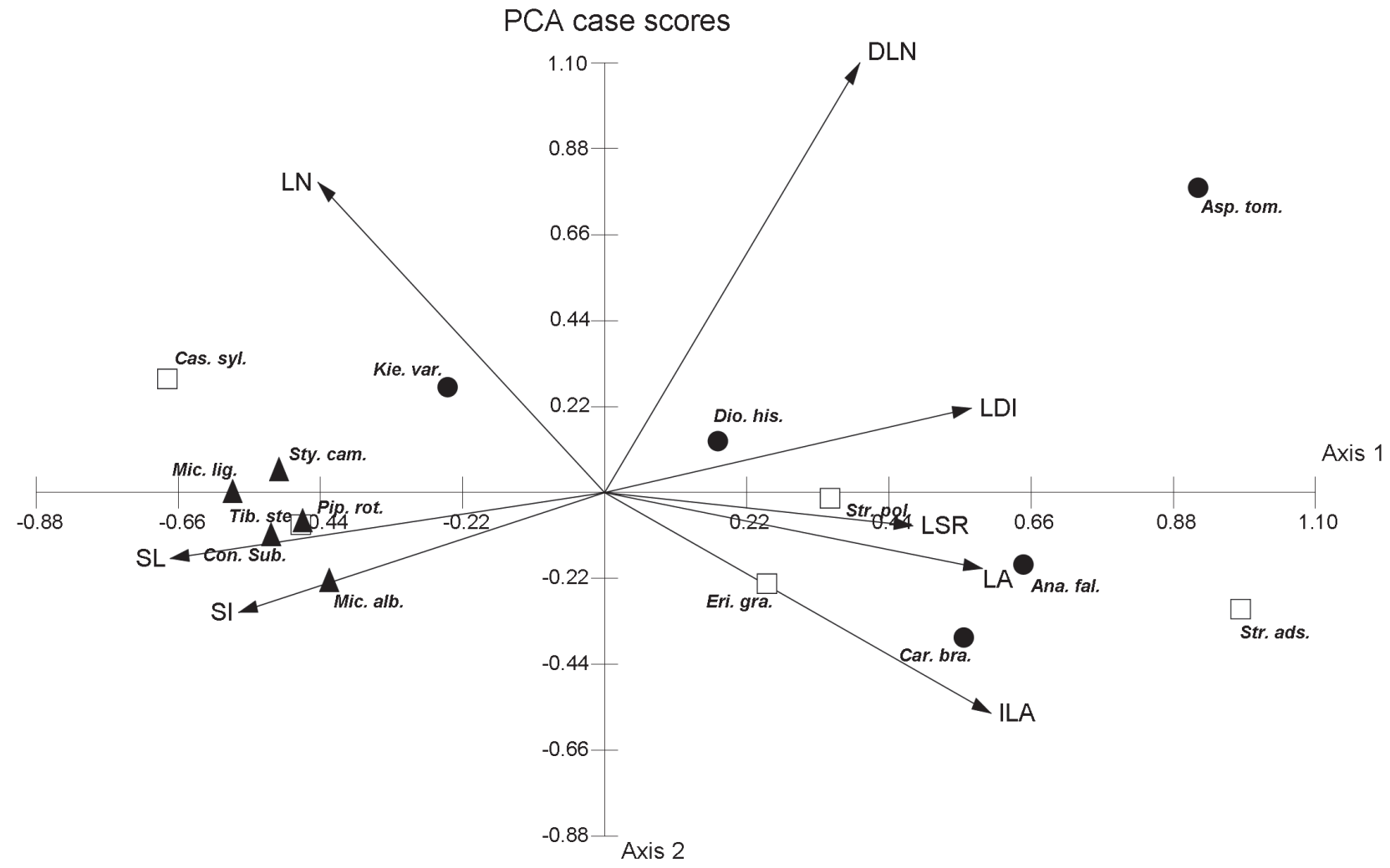

Figure 6. Principal component analyzes (PCA) utilizing morphological traits measured in shoots and leaves on 15 cerrado tree species. Deciduous, semideciduous, and evergreen species are represented by symbols $\bullet$, 口, and $\boldsymbol{\Lambda}$, respectively. Each species is indicated by six letters according to Table 1 . The dispersion was considered in a 2-dimensional space ordered by two axes. The axes 1 and 2 accounted for 59 and $16 \%$ of total data variation, respectively. SI=shoot inclination; $S L=$ shoot length; $L A=$ leaf area; $D L N=$ density of leaf number; $L D I=$ leaf display index; ILA=individual leaf area; $L N=$ leaf number; and $L S R=$ leaf/shoot ratio.

\section{DISCUSSION}

Similar irradiance along slanting shoots permits high values of $L A, L D I, D L N, I L A$, and LSR without foliage self-shading in deciduous species. On the other hand, semideciduous and evergreen species attenuate the foliage self-shading on the base of the erect shoots decreasing the $L A$, ILA and DLN. The low DLN in semideciduous and evergreen species was possible by reason of their long shoots in spite of the high leaf number per shoot. The advantage of a leaf self-shading on erect shoots in evergreen and semideciduous species is the protection against excessive irradiance, which is one of the most important causes of midday depression of carbon assimilation in cerrado trees (Franco and Lüttge, 2002). Besides, foliage self-shading could reduce the leaf transpiration during dry season. Thus, erect shoots could be an adaptation of semideciduous and evergreen trees in Cerrado for protecting the permanent foliage against the daily and the seasonal environmental stresses.

The combination of fast growth of the foliage with leaf synchronic production and high values of LA, LDI, DLN, ILA, and LSR could compensate the period without photosynthetic activity in deciduous species. On the other hand, the foliage of deciduous trees shows high exposition to environmental stresses on plagiotropic shoots. Therefore, deciduous shed totally their leaves as of the beginning of dry season avoiding the excessive irradiance combined with soil water stress and high atmospheric evaporative demand (Franco, 2002).

All deciduous, three semideciduous, and two evergreen species showed structural variation among current-year shoots. This trait was revealed mainly by negative relationship between 
LDI and SL (Yagi and Kikuzawa, 1999). Therefore, short shoots showed higher leaf area by length than long shoots, especially in deciduous trees of cerrado as found in species of temperate forest (Takenaka, 1997; Yagi and Kikuzawa, 1999; Yagi, 2000). The exponential decay of LSR with SL in all deciduous species corroborates the structural differentiation between short and long shoots, because it indicates high allocation in leaf biomass on short shoots (Yagi, 2000). The vegetative function of short shoots with high leaf area would be to increase the light interception (Takenaka, 1997). On the other hand, the vegetative function of long shoots with low values of LDI and LSR would be to expand the crown in competition with other individuals (Yagi and Kikuzawa, 1999; Yagi, 2000; Suzuki, 2003). However, the canopies in the cerrado stricto sensu physiognomy rarely touch each other, and $80 \%$ of the total irradiance reached the base of the shoots in deciduous species. Therefore, must have other explanation for structural differentiation between short and long shoots found particularly in deciduous species.

The number of leaves in a mature shoot of deciduous trees in Cerrado is the same of that number of leaf primordia enclosed within a bud by reason of the leaf pre-formation (Damascos et al., 2005; Damascos, 2008). Therefore, short shoots in deciduous tree species of cerrado tend to show higher values of LDI, DLN, and LSR than the long shoots. Contrastingly, the shoots of deciduous with high linear growth probably will present the values of shoot-foliage relationship in favor of shoot, because the leaf number is pre-determined since the bud formation. On the other hand, in semideciduous and evergreen species the leaves are neo-formed by apical meristem with the foliage production according to the shoot growth (Damascos et al., 2005; Lenza and Klink, 2006). As a consequence of foliage neo-formation, the semideciduous and evergreen cerrado trees keep more constant the shoot-leaf relationships per shoot length. Therefore, in trees of cerrado stricto sensu physiognomy, the shoot-foliage relationships are related to the kind of leaf production and to the shoot inclination instead of to the competition among shoots for the light resource.

The morphological relationships between shoot-foliage were significantly different across leaf phenological groups in Cerrado. Evergreen species is the group more homogeneous considering the leaf and shoot morphological traits analyzed together (SI, SL, LA, DLN, LDI, ILA, LN, and LSR) as revealed by their grouping behavior in PCA. Contrastingly, semideciduous showed the highest variation in shoot-foliage relationships, being scattered among evergreen and deciduous species in PCA output. Deciduous did not form an evident cluster as the evergreen species, but they showed lower dispersion than the semideciduous. Because semideciduous had intermediate mean values among phenological groups about most variables determined (LA, LDI, DLN, ILA, LSR, and shoot angle) and the highest dispersion in PCA output overlapping the 2-dimensional space of deciduous and evergreen trees, they are one group with leaf and shoot morphological traits from both semideciduous and evergreen species.

In conclusion, from deciduous to evergreen, there is an increasing gradient of foliage persistence, shoot angle and SL, and a decreasing gradient of LA, LDI, DLN, ILA, and LSR. It was evident that each leaf phenological group of tree species in Cerrado has one particular relationship between autotrophic and heterotrophic vegetative parts resulting in functional groups based on morphological canopy traits. The foliage persistence is strongly related to the shoot inclination, the type of leaf production, the irradiance extinction along shoots and to the biomass partitioning in canopy.

Acknowledgments: The agency Conselho Nacional de Desenvolvimento Científico e Tecnológico (CNPq, Brazil) has granted scholarships to the authors JPS and CHBAP and the agency Fundação de Amparo à Pesquisa de São Paulo (FAPESP, SP) to ALSA.

\section{REFERENCES}

Bucci SJ, Goldstein G, Meinzer FC, Scholz FG, Franco AC, Bustamante $M$ (2004) Functional convergence in hydraulic architecture and water relations of tropical savanna trees: from leaf to whole plant. Tree physiol. 24:891-899.

Castro AAJF, Martins FR, Tamashiro JY, Shepherd GJ (1999) How rich is the flora of Brazilian Cerrados? Ann. Mo. Bot. Gard. 86:192-226.

Cornelissen JHC, Lavorel S, Garnier E, Díaz S, Buchmann N, Gurvich DE, Reich PB, ter Steege H, Morgan HD, van der Heijden MGA, Pausas JG, Poorter $H$ (2003) A handbook of protocols for standardised and easy measurement of plant functional traits worldwide. Aust. J. Bot. 51:335-380.

Damascos MA, Prado CHBA, Ronquim CC (2005) Bud composition, branching patterns and leaf phenology in cerrado woody species. Ann. Bot 96:1075-1084.

Damascos MA (2008) Conteúdo das gemas, momento da brotação e padrão de produção de folhas em espécies lenhosas do cerrado [online]. Available from $\quad$ HTTP://www.manole.com.br/fisiologiavegetal/textos\%20corrigidos/ rhdamascos.pdf.[accessed in 06 August 2008].

Eiten G (1972) The Cerrado vegetation of Brazil. Bot. Rev. 38:201-341. 
Franco AC (2002) Ecophysiology of woody plants. In: Oliveira PS, Marquis RJ (eds), The Cerrados of the Brazil: Ecology and Natural History of a Neotropical Savanna, pp.178-197. Columbia University Press, New York.

Franco AC, Lüttge U (2002) Midday depression in savanna trees: coordinated adjustments in photochemical efficiency, photorespiration, $\mathrm{CO}_{2}$ assimilation and water use efficiency. Oecologia 131:356-365.

Franco AC, Bustamante M, Caldas LS, Goldstein G, Meinzer FC, Kozovits AR, Rundel P, Coradin VTR (2005) Leaf functional traits of Neotropical savanna trees in relation to seasonal water deficit. Trees 19:326-335.

Jackson PC, Meinzer FC, Bustamante M, Goldstein G, Franco AC, Rundel PW, Caldas L, Igler E, Causin F (1999) Partitioning of soil water among tree species in a Brazilian Cerrado ecosystem. Tree Physiol. 19:717-724.

Kanno SS (1998) Estudo ecofisiológico de duas espécies nativas do cerrado: Kielmeyera coriacea e Kielmeyera variabilis - A disponibilidade hídrica e sua relação com as trocas gasosas, o potencial hídrico foliar e a fenologia. São Carlos, Federal University of São Carlos, PhD Thesis.

Lenza E, Klink CA (2006) Comportamento fenológico de espécies lenhosas em um cerrado sentido restrito de Brasília, DF. Rev. bras Bot. 29:627-638.

Meinzer FC, Goldstein G, Franco AC, Bustamante M, Igler E, Jackson P, Caldas L, Rundel PW (1999) Atmospheric and hydraulic limitations on transpiration in Brazilian cerrado woody species. Funct. Ecol. 13:273-282.

Mendonça RC, Felfili JM, Walter BMT, Júnior MCS, Rezende AV, Filgueiras TS, Nogueira PE (1998) Flora vascular do cerrado. In: Sano SM, Almeida SP (eds), Cerrado: Ambiente e Flora, pp.289-556. EMBRAPA, Planaltina, Brasil.

Monteiro JAF, Prado CHBA (2006) Apparent carboxylation efficiency and relative stomatal and mesophyll limitations of photosynthesis in an evergreen cerrado species during water stress. Photosynthetica 44:39-45.
Oliveira FF, Batalha MA (2005) Lognormal abundance distribution of woody species in a cerrado fragment (São Carlos, southeastern Brazil). Rev. bras. Bot. 28:39-45

Paula NF (2002) Capacidade fotossintética, deciduidade e teor de nitrogênio e fósforo em espécies lenhosas do cerrado. São Carlos, Federal University of São Carlos, PhD Thesis.

Prado CHBA, Wenhui Z, Rojas MHC, Souza GM (2004) Seasonal leaf gas exchange and water potential in a woody cerrado species community. Braz. J Plant Physiol. 16:7-16.

Ribeiro JF, Walter BMT (1998) Fitofisionomias do Bioma Cerrado. In: Sano SM, Almdeida SP (eds), Cerrado: Ambiente e Flora, pp.89-166. EMBRAPA, Planaltina, Brasil.

Sarmiento G (1984) The Ecology of Neotropical Savannas. Harvard University Press, Cambridge.

Suzuki M (2003) Size structure of current-year shoots in mature crowns. Ann. Bot. 92:339-347.

Takenaka A (1997) Structural variation in current-year shoots of broad leaved evergreen tree saplings under forest canopies in warm temperate Japan. Tree Physiol. 17:205-210.

Yagi T, Kikuzawa K (1999) Patterns in size-related variations in current-year shoot structure in eight deciduous tree species. J. Plant Res. 112:343-352.

Yagi T (2000) Morphology and biomass allocation of current-year shoots of ten tall species in cool temperate Japan. J. Plant Res. 113:171-183.

Zar JH (1999) Biostatistical analysis. $4^{\text {th }}$. Prentice Hall, New Jersey. 